\title{
Information Technologies as a Factor of Evolution of Tax Administration
}

\author{
Sabitova N.M.a \\ Khafizova A.R. ${ }^{\text {b }}$
}

a b Kazan Federal University, Institute of Management, Economics and Finance, Kazan, 420008, Russia

Email: sabitovanm@mail.ru

\section{Doi:10.5901/mjss.2015.v6n1s3p169}

\section{Abstract}

This publication describes the comparative analysis of taxing activity in different countries in terms of using information technologies and communication with the taxpayers through electronic means, as well as development of web services. Particularly, the document refers to the comparative country-specific data of cost structure for tax administration, electronic filing of personal/corporate income tax, automated application of budget settlements within Russia provided to taxpayers and others. Since its establishment, the Federal Tax Service of Russia deals with enhancement of tax administration all over the country, however, the tax authorities are not as effective as required for the time being. The point is to ensure the growth of tax revenues and enhance the quality of services rendered.

Keywords: Tax authorities, tax administration, quality of services, communication through electronic means

\section{Introduction}

The perfection of tax administration is a significant trend to reform the national administration of Russia, including but not limited to optimisation of tax activities, providing comfort conditions for joint work of taxpayers and government authorities and development of electronic document management. As the Russian Federation is a member of international taxation organisations such as the Intra-European Organisation of Tax Administration (IOTA), the Coordination Board of CIS tax leaders, it is important to focus on the global tax administration practice. The objective of this cooperation is the exchange of experience between the tax authorities of different countries with regard to enhanced tax administration effectiveness.

\section{Theory}

As is already discussed, the global practice means by the perfection of tax administration the improvement in quality of services subject to render to the taxpayers, using the current information technologies by tax authorities and updating the document flow. The matters of how the tax authorities engage with the taxpayers are covered in the publications of the following authors: Rusdi Hidayat N., Suhadak, Darminto, Handayani S. R., Otok B. W. [1], Hauptman L., Horvat M., Korez-Vide R. [2], Alm J., Cherry T., Jones M., McKee M., Jackson B. R. [3], [4], [5]. The authors: Gopaul A. [6], Li D., He Y., Xu Y., Fan Y. [7], Dias E. M., De Mello N. O., Fernandez, M. L. A. [8], Tay, A.S.M. [9], Ostasius, E., Petraviciute, Z. [10] have studied the development of information technologies and electronic document management using world-wide case studies as an example. The aspects of international fiscal cooperation are described in the publication of Kudrle, R.T. [11].

The variety of approaches to the tax administration system, which is intrinsically associated with difference between tax systems, however, identifies some general development trends of tax activity growth notably:

- Reforms that are aimed to optimisation of tax administration, enhancement of its efficiency; introduction of the advanced corporate methods of strategic management and planning;

- Introduction of information technologies to enhance tax control and a taxpayer information system that will result in increased performance of tax officers;

- Engagement of private agencies in performing individual functions for tax authorities; and

- International cooperation of the revenues.

The solution to these problems in all countries is only possible if the key society institutions are at a high level, the technological and social infrastructure is set up as well as codes and values are provided that maintain the good performance of all the market participants. 


\section{Results}

The Russian taxation system for both the legal bodies and individuals keeps constantly updating taking the world practice into consideration. The public administration system is being also improved including the tax administration, which is one of the taxation priorities of the country. The Ministry of Finance of the Russian Federation uses the fiscal policy on the global tax trends. For drafting the budgets of the Russian budget system, a document "Key Trends of Fiscal Policy of the Russian Federation for the Subsequent Financial Year..." will be issued that provides a comparative analysis of countrywise taxation loads in terms of tax types and taxpayers. However, a comparative analysis is essential for measures that characterise the level and quality of tax administration, in particular, such information as cost for tax administration, cost structure, personal/corporate income tax return by electronic means, and introduction of automated application of budget settlements within Russia provided to taxpayers and others should be available. This document does not refer to such information although it may be useful for the taxpayers as well and contribute to the transparency of Russian fiscal system. However this information is available in the official publications of the Organization for Economic Cooperation and Development (OECD).

We are going to analyse some comparative measures of concern for tax administration in this document. The tax cost structure analysis provides more details. The human resources are the key feature of tax administration. The worldwide practice suggest that the labor cost varies from $60 \%$ to $90 \%$ of the total tax expenditures. The average countryspecific labor costs are about $70 \%$ of the total tax administration expenditures (Table 1).

For the countries of OECD, the labor costs are just over those not being the OECD member, which can be explained by higher wage level in the developed economies that overweighs other tax costs in the relative measurement. However, in some highly-developed countries with the labor cost much lesser than the average value, this fact is determined by higher level of information technologies that reduce the number of employees. This can be specifically seen in such countries as the UK and the USA. The IT costs in the non-OECD countries are low. This measure, however, keeps growing over the last years. Therefore, the statistic data confirm that the current tax administration is going to actively use the information technologies.

Table 1. Cost structure for tax administration [13] percentage of total expenditure

\begin{tabular}{|c|c|c|c|c|c|c|c|c|c|c|}
\hline \multirow[b]{2}{*}{ Countries } & \multicolumn{2}{|c|}{2005 year } & \multicolumn{2}{|c|}{2006 year } & \multicolumn{2}{|c|}{2007 year } & \multicolumn{2}{|c|}{2008 year } & \multicolumn{2}{|c|}{2009 year } \\
\hline & 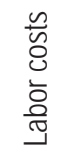 & 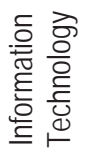 & 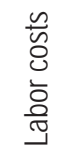 & 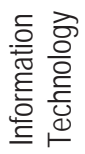 & $\begin{array}{l}\frac{0}{0} \\
0 \\
0 \\
\overline{0} \\
\text { త్ }\end{array}$ & 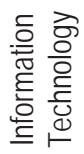 & 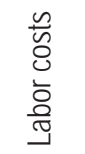 & 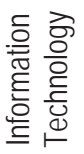 & $\begin{array}{l}\frac{0}{0} \\
0 \\
0 \\
\overline{0} \\
\frac{0}{J}\end{array}$ & 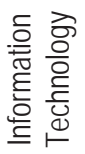 \\
\hline OECD countries: & 75,5 & 11,3 & 72,7 & 11,4 & 73,1 & 11,5 & 71,1 & 12 & 72,4 & 11,6 \\
\hline United Kingdom & 63 & n.a. & 60,1 & 22,7 & 61,2 & 20,2 & 58,8 & 20,3 & 59,1 & 16,3 \\
\hline Canada & 81,5 & 9 & 82 & 8,9 & 83 & 8,4 & 82,8 & 11,4 & 83,9 & 12,6 \\
\hline United States & 71,5 & 16,1 & 71,3 & 15,9 & 71,6 & 15,1 & 70,4 & 15,8 & 71,5 & 14,9 \\
\hline France & 78,6 & 6,1 & 79,3 & 5,1 & 79,1 & 5,3 & 81,3 & 4,2 & 81,1 & 4,2 \\
\hline Germany & 84,3 & 5,5 & 84,3 & 5,1 & 83,3 & 5,3 & 83,7 & 5,7 & 82,3 & 6,4 \\
\hline Japan & 80,2 & 9,7 & 80,5 & 9,2 & 81,1 & 8,5 & 80,7 & 8,1 & 80,8 & 8,3 \\
\hline Non-OECD countries: & 69,6 & 6,6 & 69,7 & 7,9 & 72,1 & 8 & 63,4 & 9,7 & 63,7 & 11,7 \\
\hline India & n.a. & n.a. & n.a. & n.a. & n.a. & n.a. & 60 & n.a. & 65,5 & n.a. \\
\hline Russia & n.a. & n.a. & n.a. & n.a. & n.a. & n.a. & 66,5 & 6,7 & 68,2 & 5,7 \\
\hline All countries & 70,1 & 10,2 & 70,2 & 10,6 & 71,1 & 10,7 & 68,78 & 11,3 & 69,7 & 11,7 \\
\hline
\end{tabular}

Currently, most of the industrial countries use electronic filing and online services of providing information to the taxpayers. Electronic filing of the personal income tax return is most popular in the USA, the UK and Canada (Table 2). 
Table 2. Personal income tax returns: use of electronic filling [14] in percent

\begin{tabular}{|c|c|c|c|c|}
\hline Country & Year begun & 2004 year & 2009 year & 2011 year \\
\hline \multicolumn{5}{|l|}{ OECD countries: } \\
\hline United Kingdom & 2000 & 17 & 73 & 77 \\
\hline Canada & 1993 & 49 & 58 & 62 \\
\hline United States & 1986 & 47 & 65 & 76 \\
\hline France & 2001 & 4 & 27 & 33 \\
\hline Germany & 1999 & 7 & 30 & 32 \\
\hline Japan & 2004 & 0 & 31 & 44 \\
\hline \multicolumn{5}{|c|}{ Non-OECD countries: } \\
\hline India & n.a. & n.a. & 17 & 13,1 \\
\hline Russia & 2006 & 0 & 9 & 3 \\
\hline
\end{tabular}

As is seen from Table 2, Russia is not within the leaders. In Russia, legal bodies use electronic filing that is also specific to the developed countries (Table 3).

Table 3. Corporate income tax returns: use of electronic filling [15] in percent

\begin{tabular}{|l|c|c|c|c|}
\hline Country & Year begun & 2004 year & 2009 year & 2011 year \\
\hline OECD countries: & \multicolumn{5}{|l|}{} \\
\hline United Kingdom & 2004 & 1 & 16 & 42 \\
\hline Canada & 2002 & 2 & 21 & 46 \\
\hline United States & 2004 & 1 & 25 & 44 \\
\hline France & 1991 & 26 & 77 & 81 \\
\hline Germany & n.a. & 0 & 0 & n.a. \\
\hline Japan & 2004 & 0 & 38 & 58 \\
\hline Non-OECD countries: & \multicolumn{5}{|l}{} \\
\hline India & n.a. & 0 & n.a. & 1,25 \\
\hline Russia & n.a. & 0 & 12 & 57 \\
\hline
\end{tabular}

The average data for the OECD countries show that the electronic corporate tax return is $68 \%$ in 2011 , which is in excess of the percentage for non-OECD countries. However, an electronic tax returns system for both the corporate income tax and other tax payments has been actively developing in Russia in recent years. It is due to that the one of the current features of tax administration is enhancement of quality and expanded range of services rendered to the taxpayers. The first thing to mention is the increase in electronic tax returns and the number of taxpayers, who have a contact-free access to the tax database to check their budget settlements. Now Russian taxpayers may receive the following formalised documents upon request: A document providing tax, charge, fine and penalty settlements; extracts from budget settlements; a list of tax returns (settlements) and accounting statements for the report year; and a reconciliation report of tax, charge, fine and penalty settlements.

In 2012, the percentage of taxpayers - companies and individual entrepreneurs having access to the personalised information on budget settlements through communication channels and via the Internet - is $61.9 \%$ of the total number of actual taxpayers being companies and individual entrepreneurs (Fig. 1).

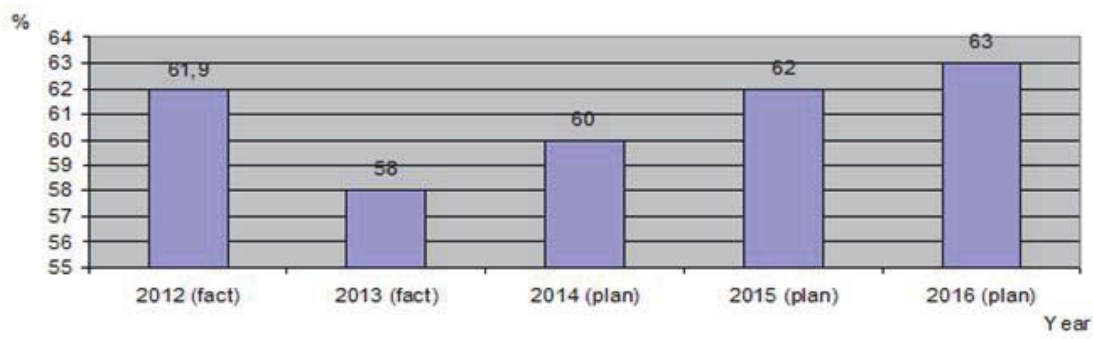

The percentage of Russian tax pay ers having access to the personalised information on budget settlements
through communication channels and via the Intemet

Fig.1. The percentage of Russian taxpayers having access to the personalised information on budget settlements through communication channels and via the Internet. 
Despite the development of electronic document management, the percentage of Russian taxpayers having access to the personalised information on budget settlements through communication channels and via the Internet is low. This number is going to slightly increase over 2014-2016. The plan is for Russia to achieve $80 \%$ by 2020 .

The online services become a frequent practice worldwide. For example, the official website of the Her Majesty's Revenue and Customs (HMRC) provides online services for the taxpayers to fill in the tax return forms in electronic format, obtain information on how to fill in the return forms, rates and miscellaneous terms of taxation, apply for the deductions and others. In addition, many countries have been using the service of taxpayer account since recently. This service is a helpful tool for the taxpayers to fill in their tax return forms, pay the dues, online check/settle arrears, apply to the revenue services, apply for the deductions and sign in for a taxpayer ID. The average number of the employees engaged in this activity is about $30 \%$ of the total number of the tax officials. The IT specialists account for about $10-15 \%$.

The website of the Federal Tax of Russia also provides links to the ongoing services. Development of the online services will make it possible to provide information to the taxpayers at a more qualitative level. Thus, multiple expert assessments suggests that website of the Federal Tax of Russia is the most demanded, informative and popular website among the public websites. Near three million visitors use it every month. The website of the Federal Tax of Russia provides links to the services, which number increases from year to year. Now, 30 online services are available, among which are "Corporate Taxpayer Account", "Individual Taxpayer Account", "Pay the tax", "Property taxes: rates and privileges", "Inquire About Complaint" and others.

Therefore, the quality of tax services means online cooperation between the tax authorities with the taxpayers, online providing the entire scope of information to the taxpayers, based on which they undertake in terms of the budget.

The taxation authorities in the modern developed economies delegates some features to the private agencies. The following activities as tax collections through private banks and engagement of independent auditors (who should check the correct profit calculations of banks, insurance companies and joint-stock companies) have already become a practice. In addition, it should be noted that private agencies are involved into the software development for tax bodies and processing mass data. However, private agencies in Russia are not engaged in performing individual functions for tax authorities.

A specific area of tax administration is the international cooperation between tax authorities in different formats from single or periodic consulting and mutual data exchange regarding amendments of tax laws to conclusion of longterm tax agreements and migration to a full-scale tax harmonisation. The latter is specifically characteristic of the EU and OECD countries. The objective need for cooperation between the Federal Tax Service of Russia and similar structures of other countries bases primarily on the Russia's external economic activity, which is in line with the international economic relations and is of an international nature.

Therefore, the following development trends of the global tax practice may be identified: Introduction of a 'resultbased management' model for tax authorities; using current technologies in the tax activity; further introduction and development of online services for taxpayers; and evolution of international tax cooperation.

\section{Conclusions}

The analysis of theories and practical aspects of world taxation mainstreams yields the following conclusions:

1. The comparative analysis of tax business in different countries in terms of tax administration revealed that Russia focuses efforts on the comfort conditions for communication between taxpayers and tax authorities.

2. It is a good practice in Russia to develop online communication of tax authorities with taxpayers, using newest information technologies in undertaking tax activities. The wide use of current information technologies enables automation of the entire process of tax administration.

3. As part of international tax cooperation, the automated information systems are being developed that ensure tax business, facilitate communication at a quality level and exchange the information between the tax authorities worldwide. Making of such system will allow for more effective and accurate employing the information component of tax authorities. The information exchange between tax authorities in different countries should also develop to reduce double taxation significantly.

\section{References}

Rusdi Hidayat N., Suhadak, Darminto, Handayani S. R., Otok B. W. Measurement model of service quality, regional tax regulations, taxpayer satisfaction level, behavior and compliance using confirmatory factor analysis // World Applied Sciences Journal Volume 29, Issue 1, 2014. pp. 56-61. 
Hauptman L., Horvat M., Korez-Vide R. Improving tax administration's services as a factor of tax compliance: The case of tax audit // Lex Localis Volume 12, Issue 3, 2014. pp. 481-501.

Alm J., McKee M. Tax compliance as a coordination game // Journal of Economic Behavior and Organization Volume 54, Issue 3, 2004. pp. 297-312.

Alm J., Jackson B. R., McKee M. Getting the word out: Enforcement information dissemination and compliance behavior // Journal of Public Economics Volume 93, Issue 3-4, 2009. pp. 392-402.

Alm J., Cherry T., Jones M., McKee M. Taxpayer information assistance services and tax compliance behavior // Journal of Economic Psychology Volume 31, Issue 4, 2010. pp. 577-586.

Gopaul A. An assessment of the use of information technology tools and E-business by informal sector entrepreneurs in Mauritius // Communications in Computer and Information Science Volume 31, 2013. pp. 306-315.

Li D., He Y., Xu Y., Fan Y. Measures of building tax information // Advances in Intelligent and Soft Computing Volume 158AISC, Issue VOL1, 2012. pp. 11-15.

Dias E. M., De Mello N. O., Fernandez M. L. A. The evolution of the electronic tax documents in Latin America // WSEAS Transactions on Systems and Control Volume 5, Issue 12, 2010. pp. 902-909.

Tay, A.S.M. Technology adoption gone wrong // 15th Americas Conference on Information Systems 2009, AMCIS 2009 Volume 7, 2009. pp. 4495-4500.

Ostasius, E., Petraviciute, Z. Assessment of E-services and their systems // Engineering Economics Volume 21, Issue 4, 2010. pp. 360367.

Kudrle, R.T. Governing Economic globalization: The pioneering experience of the OECD // Journal of World Trade Volume 46, Issue 3, 2012. pp. 695-732.

Official website of OECD [online]: Cost of collection ratios (administrative costs/net revenue). - Available at: <http:// www.oecd.org/ site/ctpfta/taxadministrationdatabase.htm >

Lykov L.N. Tax systems of foreign countries: textbook. - M.: Publisher Yurait, 2013. - 428 p.

Official website of OECD [online]: Personal income tax returns: Use of electronic filing and pre-filling. - Available at: <http:// www.oecd. $\mathrm{org} / \mathrm{site} / \mathrm{ctpfta/taxadministrationdatabase.htm} \mathrm{>}$

Official website of OECD [online]: Corporate income tax returns: Use of electronic filing and pre-filling. - Available at: <http:// www.oecd. org/site/ctpfta/taxadministrationdatabase.htm >

Varlamova J.A., Larionova N.I. Economic behavior of households: cross-country comparison. Life Science Journal 2014; 11(6s): 409413.

I.Sh. Khasanov, Three-sector structure of the national economy of Russia // Asian Social Science, Volume 10, 2014, Pages $217-224$. 